\title{
Лев Урало-Казахстанских степей... (Памяти Л.Л. Гайдученко)
}

\section{(С) 2021 г. Лошакова Т.Н., Шевнина И.В.}

Keywords: archaeology, L. Gayduchenko, paleontologist, zoologist, osteology, burn-on, animal domestication

Түйін сөздер: археология, Л. Гайдученко, палеонтолог, зоолог, остеология, күйдіру, жануарларды қолға үйрету

Ключевые слова: археология, Л.Л. Гайдученко, палеонтолог, зоолог, остеология, пригар, доместикация животных

\section{Tatyana Loshakova ${ }^{1}$, Irina Shevnina ${ }^{2}$}

${ }^{1}$ Corresponding author, Senior Researcher, A.Kh. Margulan Archaeology Institute, Almaty, Kazakhstan. E-mail: loshakovat@mail.ru

${ }^{2}$ Candidate of Historical Sciences, Doctor of Philosophy (PhD), Researcher, A. Baitursynov Kostanay Regional University, Kostanay, Kazakhstan. E-mail: shevnina i@mail.ru

\section{Lion of Ural-Kazakhstan steppes... (In memory of L. Gayduchenko)}

\begin{abstract}
The article summarizes the main milestones of the creative path of the famous archaeozoologist Leonid Gayduchenko. In the scientific environment, the name of L. Gayduchenko is associated with the study of monuments of ancient history in the aspect of solving the problems of paleoecology, the evolution of economic activity, the development of ancient technologies in the Ural-Kazakhstani steppes. Chronologically, the complexes he studied cover the period of the Era of Stone and Paleometal. Among the monuments whose materials L. Gayduchenko studied are Paleolithic locations on Lake Maraldy in Northeast Kazakhstan, the Upper Paleolithic site on the Irtysh, the Toktaul site, the settlements of Kozhay 1, Botay, Kumkeshu 1, Borly, Toksanbay, Konezavod I, Taldysay and Dongal, the burial grounds of Halvay and Taksay 1. Special attention should be paid to the author's methodology for the study of burn-on on vessels and the study of the development of food resources by the ancient population. The breadth of interests of L. Gayduchenko is evidenced by his experiments on the reconstruction of ancient copper smelting technologies and the development of the problem of construction of the sacrificial complexes of the Bestamak burial ground. The recognition of the scientific heritage of L. Gayduchenko and his high humanity qualities are evidenced by the memories of colleagues.
\end{abstract}

Citation: Loshakova T., Shevnina I. Lion of Ural-Kazakhstan steppes... (In memory of L. Gayduchenko). Kazakhstan Archeology. 2021, 4 (14), 182-192 (in Russian). DOI: $10.52967 /$ akz2021.4.14.182.192

\section{Лошакова Татьяна Николаевна ${ }^{1}$, Шевнина Ирина Викторовна ${ }^{2}$}

${ }^{1}$ корреспондент авторы, аға ғылыми қызметкер, Ә.Х. Марғұлан атындағы Археология институты, Алматы, Қазақстан. E-mail: loshakovat@mail.ru

${ }^{2}$ тарих ғылымдарының кандидаты, философия докторы (PhD), ғылыми қызметкер,

А. Байтұрсынов атындағы Қостанай аймақтық университеті, Қостанай, Қазақстан. E-mail: shevnina_i@mail.ru 
Лошакова Т.Н., Шевнина И.В. Лев Урало-Казахстанских степей...

\section{Орал-Қазақстан далаларының арыстаны... (Л.Л. Гайдученконы еске алу)}

Аннотация. Мақалада белгілі археозоолог Леонид Леонидович Гайдученконың шығармашылық жолының негізгі кезеңдері келтірілген. Ғылыми ортада Л.Л. Гайдученконың есімі ежелгі тарих ескерткіштерін палеоэкология, шаруашылық қызметінің эволюциясы, Орал-Қазақстан даласындағы ежелгі технологиялардың дамуы мәселелерін зерттеумен тығыз байланысты. Хронологиялық тұрғыдан ол зерттеген кешендер тас пен палеометалл дәуірінің кезеңін қамтиды. Л.Л. Гайдученко зерттеген ескерткіштердің ішінде көлдегі палеолиттік орындарды: Қазақстанның солтүстікшығысындағы Маралды, Ертістегі жоғарғы палеолит тұрағы, Тоқтауыл тұрағы, Қожай 1, Ботай, Құмкешу 1, Борлы, Тоқсанбай қоныстары, Конезавод I, Талдысай және Доңғал, Қалыбай және Тақсай 1 қорымдарын атауға болады. Ол әзірлеген ыдыстардағы күйіктерді зерттеу және ежелгі халықтың тамақ ресурстарын игеру мәселесін зерттеу бойынша авторлық әдістеме ерекше назар аударуға тұрарлық. Л.Л. Гайдученконың ғылыми қызығушылығының кеңдігін мыс балқытудың ежелгі технологияларын қайта құру және Бестамақ қорымының құрбандық кешендерін қосу мәселесін жасау бойынша жүргізген эксперименттері дәлелдейді. Л.Л. Гайдученконың ғылыми мұрасын және оның жоғары адамгершілік қасиеттерін тануға әріптестерінің естеліктері куә бола алады.

Сілтеме жасау үшін: Лошакова Т.Н., Шевнина И.В. Орал-Қазақстан далаларының арыстаны... (Л.Л. Гайдученконы еске алу). Қазақстан археологиясы. 2021. № 4 (14). 182-192-бб. (Орысша). DOI: 10.52967/akz2021.4.14.182.192

\section{Лошакова Татьяна Николаевна ${ }^{1}$, Шевнина Ирина Викторовна ${ }^{2}$}

${ }^{1}$ автор-корреспондент, старший научный сотрудник, Институт археологии им. А.X. Маргулана, г. Алматы, Казахстан. E-mail: loshakovat@mail.ru

${ }^{2}$ кандидат исторических наук, доктор философии (PhD), научный сотрудник, Костанайский региональный университет им. А. Байтурсынова, г. Костанай, Казахстан. E-mail: shevnina_i@mail.ru

Аннотация. В статье кратко излагаются основные вехи творческого пути известного археозоолога - Леонида Леонидовича Гайдученко. В научной среде имя Л.Л. Гайдученко связано с исследованием памятников древней истории в аспекте решения проблем палеоэкологии, эволюции хозяйственной деятельности, развития древних технологий в Урало-Казахстанских степях. В хронологическом отношении изученные им комплексы охватывают период эпохи камня и палеометалла. Среди памятников, материалы которых изучал Л.Л. Гайдученко, можно назвать палеолитические местонахождения на оз. Маралды в Северо-Восточном Казахстане, верхнепалеолитическую стоянку на Иртыше, стоянку Токтаул, поселения Кожай 1, Ботай, Кумкешу 1, Борлы, Токсанбай, Конезавод I, Талдысай и Донгал, могильники Халвай и Таксай 1. Особого внимания заслуживает разработанная им авторская методика по изучению пригаров на сосудах и изучение вопроса освоения пищевых ресурсов древним населением. О широте интересов Л.Л. Гайдученко свидетельствует проведенные им эксперименты по реконструкции древних технологий плавки меди и разработка проблемы сложения жертвенных комплексов могильника Бестамак. О признании научного наследия Л.Л. Гайдученко и его высоких человечествах качествах свидетельствуют воспоминания коллег.

Для цитирования: Лошакова Т.Н., Шевнина И.В. Лев Урало-Казахстанских степей... (Памяти Л.Л. Гайдученко). Археология Казахстана. 2021. № 4 (14). С. 182-192. DOI: $10.52967 / \mathrm{akz} 2021.4 .14 .182 .192$ 
«Кто посвятит свою жизнь служению науке, того имя и после смерти будет бессмертным»

A. Навои

\section{Введение}

Леонид Леонидович Гайдученко - человек, который более 50-ти лет своей жизни посвятил исследованию памятников древней истории. Его привлекала не только палеозоология, а также проблемы палеоэкологии, эволюции хозяйственной деятельности древнего человека, развитие древних технологий. В воспоминаниях о нем всегда подчеркивается, что общаться с ним было легко и увлекательно, интересно спорить и обсуждать научные проблемы (рис. 1).

\section{Немного биографии}

Родился Л.Л. Гайдученко 18 мая 1948 г. в г. Первомайск Ворошиловградской области (ныне Луганская обл. - прим. авт.). Позже семья переезжает в г. Павлодар, где после окончания школы, в возрасте 17 лет, он поступает на работу в таксомоторный парк учеником слесаря, а немногим позже был принят на работу научным сотрудникомисторико-краеведческого музея. В 1970 г. Леонид Леонидович возглавил краеведческий и археологический кружок при «Детской экскурсионно-туристической станции» города. В 1971 г. Л.Л. Гайдученко становится студентом Павлодарского педагогического института по специальности «биология».

Во время обучения в Институте был принят лаборантом на кафедру зоологии. С этого момента и начинается его «путь в большую науку». В 1977 г., завершив обучение в Институте и получив диплом с присвоенной квалификацией «учитель биологии средней школы», Л.Л. Гайдученко остается преподавателем на кафедре

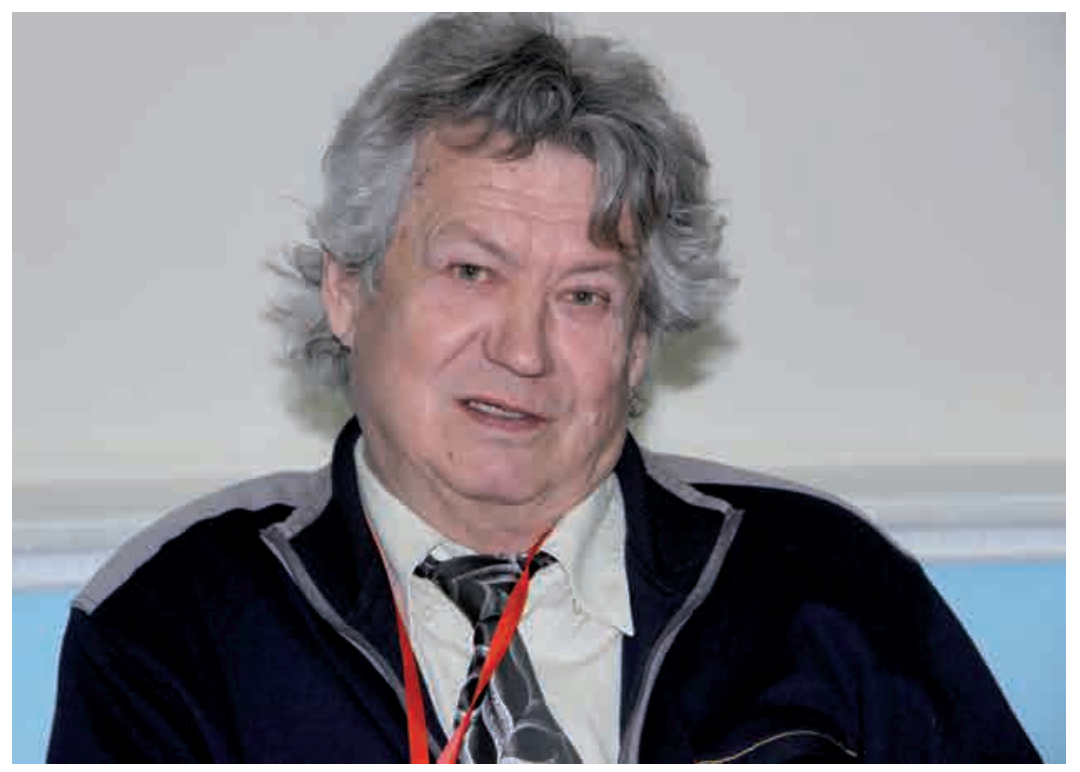

Рис. 1. Л.Л. Гайдученко. Маргулановские чтения-2011. Астана. Фото Э.Р. Усмановой 1-сур. Л.Л. Гайдученко. Марғұлан оқулары-2011. Астана. Сурет Э.Р. Усманованікі Fig. 1. L. Gayduchenko. Margulan readings-2011. Astana. Photo by E. Usmanova 
Лошакова Т.Н., Шевнина И.В. Лев Урало-Казахстанских степей...

зоологии, где и проработал вплоть до 1986 г. В этом же году Леонид Леонидович был принят по конкурсу на место преподавателя в Кустанайский педагогический институт, где уже в декабре обозначенного года он возглавил кафедру зоологии. Тогда же, в 1986 г., им была успешно защищена диссертация на тему «Позвоночные, палеоландшафты и палеоклиматы неогена Павлодарского Прииртышья» и была присуждена степень кандидата геолого-минералогических наук [Гайдученко 1986]. Через несколько лет Л.Л. Гайдученко становится деканом биологического факультета, а в 1996 г. начинается новый этап в жизни исследователя - он переезжает в г. Челябинск и поступает работать преподавателем в Челябинский государственный университет (ЧелГУ) на кафедру археологии, этнографии и социо-естественной истории. В 2002 г. там же, в ЧелГУ, занимает должность заместителя директора Научно-образовательного комплекса (НОК) по изучению проблем природы и человека, при этом являясь заместителем директора по науке Центра «Аркаим» и старшим научным сотрудником Института археологии УрО РАН. С 2012 г. возглавляет учебнопроизводственный отдел археологии, этнографии, современной и исторической экологии при ЧелГУ, где практически в это же время становится заведующим сектором почвоведения лаборатории биоценозов и мониторинга природной среды. Кроме того, Леонид Леонидович посвящал много времени и сил работе с детьми, являясь преподавателем НОЦ школы № 12 г. Челябинска.

Записи в трудовой книжке - всего лишь слова, за которыми кроются годы труда, поисков, экспериментов, таланта ученого-исследователя и сил организатора.
Его активная жизненная позиция проявлялась всегда и во всем. Человек не равнодушный, он в 2000 г. становится учредителем Челябинского городского общественного движения «Спасем озеро Смолино» [Спасем озеро Смолино...]. Как популяризатор древней истории края, активно участвует в разработке туристических маршрутов в степном Зауралье, став участником проекта «Южное кольцо» [Семинар-практикум в с. Чесма]. Много сил и времени Леонид Леонидович отдавал воспитанию молодого поколения. Бывшие студенты и школьники, которых он когда-то увлек древностями родного края, повзрослев, помогали и поддерживали своего наставника. Л.Л. Гайдученко скончался 18 марта 2021 г. на 73-м году жизни, он внес значительный вклад в археологическое изучение Казахстана.

\section{Палеоозоология}

Одна из первых работ исследователя была посвящена гиппарионовой фауне павлодарского местонахождения «Гусиный переплет» [Гайдученко и др. 1978]. Интерес к палеонтологии положил начало научным изысканиям. Однако интерес к непознанному был настолько велик, что выходил за рамки палеонтологических древностей. Позже в исследовательский круг интересов вошли памятники археологии. В совместной экспедиции с Ж. К. Таймагамбетовым исследовались палеолитические местонахождения на оз. Маралды в Северо-Восточном Казахстане [Гайдученко, Таймагамбетов 1982], верхнепалеолитическая стоянка на Иртыше [Гайдученко 1982]. Изыскания на памятниках каменного века продолжены многим позже, когда изучался материал стоянки Токтаул [Гайдученко 2013]. За время работы на палео- 
зоологическом поприще Л.Л. Гайдученко изучены огромные коллекции с поселенческих комплексов Казахстана. Несколько сезонов исследовались колоссальные коллекции с поселений Кожай 1, Ботай, Кумкешу 1, Борлы, Токсанбай, Конезавод I, Талдысай и Донгал [Калиева, Гайдученко, Логвин 1989; Гайдученко Мерц, 2012; Гайдученко 2012; 2013a; Гайдученко, Зайберт и др. 2013; Гайдученко 2017; Гайдученко, Ломан 2015], могильников Халвай и Таксай 1 [Гайдученко 2015; 2015a-в]. Значительный блок исследований Леонида Леонидовича посвящен разработке вопросов доместикации животных и эволюции хозяйства древнего населения УралоКазахстанских степей. В рамках данного направления исследователем была разработана авторская методика по изучению пригаров на сосудах [Гайдученко, Зданович Д.Г. 2002; Грушин, Гайдученко 2013; Гайдученко, Кирюшин 2015; Гайдученко 2015г]. В работах исследователя освещались проблемы становления и развития хозяйственной деятельности древнего населения, начиная с эпохи неолита [Гайдученко 1998; 2005; Гайдученко, Калиева, Логвин 1989]. Большой вклад Л.Л. Гайдученко внес в изучение вопросов природопользования и освоения пищевых ресурсов древним населением [Гайдученко 1999; 2000; Гайдученко, Зданович Г.Б. 2000]. Особое внимание ученого привлекали жертвенные комплексы и роль использования костей животных в ритуальных выкладках на поселениях и могильниках [Гайдученко 2002]. Ярким тому примером служат также работы, посвященные особенностям сложения жертвенных комплексов могильника Бестамак [Гайдученко 2011; 2011a].
Круг интересов ученого, как и его познания, был обширен. Его интересовало все, что происходило вокруг - материалы, находки, памятники, люди; его идеи всегда вызывали бурную реакцию и дискуссии.

Можно подробно остановиться на его работах и дать оценку его научным трудам. Но мы, задумываясь о содержании статьи, хотели, прежде всего, чтобы люди, которые его знали, работали с ним, вспомнили и рассказали о нем. Поэтому мы решили поместить в статью воспоминания археологов старшего поколения, с которыми Леонид Леонидович тесно сотрудничал.

\section{Представитель первой плеяды} Павлодарской научной интеллигенции

B.K. Мерu, кандидат исторических наук, доцент кафедры истории Павлодарского государственного университета им. С. Торайгырова, директор Объединенного археологического научно-исследовательского центра им. А.Х. Маргулана: «Л.Л. Гайдученко - представитель первой плеяды Павлодарской научной интеллигенции, формировавшейся в 60-х годах прошлого столетия. Это поколение людей, обладавших невероятным энтузиазмом, которым они заражали всех, кто мечтал о больших открытиях. Именно на это время приходится наивысший уровень развития науки Казахстана, в которой он оставил заметный след. Его колыбелью было Павлодарское Прииртышье с богатейшими палеонтологическими и археологическими памятниками и интереснейшим историко-краеведческим музеем, где Леонид Леонидович с детства, по словам бывшего директора И.В. Лагутина, был завсегдатаем, постоянно приносившим палеонтологические и археологические находки, участвовал в краеведческих экспедициях музея, а 
затем, поступив на биологический факультет Павлодарского пединститута, выбрал специальность палеозоолога. Работая в Павлодарском Прииртышье, он открыл много палеонтологических и археологических памятников, среди них можно назвать такие палеолитические стоянки, как Маралды 1, 2, местонахождение Жанааул, Павлодарскую стоянку, стоянки-мастерские на Старом Экибастузе и многие другие, о которых он не успел рассказать. Работая на стыке палеонтологии и археологии в 1980-х гг., он активно включился в проблематику доместикации лошади на территории Казахстана. Еще до получения неопровержимых доказательств на основе палеогеномных исследований, он морфологическим методом обосновал принадлежность терсекской, ботайской и борлинской лошади к домашним видам. Археозоологией Урало-Казахстанских степей он занимался более 30 лет, доказывая, что на рубеже неолита и энеолита здесь уже были не только домашние лошади, но и крупный рогатый скот. К сожалению, его фундаментальный труд, посвященный палеофауне Казахстана, остался незаконченным, не реализованы также многие планы ученого, не осталось у него и преемников».

\section{Кустанайский} период Леонидыча

О своем сотрудничестве с Леонидом Леонидовичем так вспоминают В.Н. Логвин и С.С. Калиева: «Наше сотрудничество началось, когда он переехал в Кустанай и стал работать на биологическом факультете КГПИ (Кустанайского государственного педагогического института - прим. авт.). Произошло это в начале 80 -х годов прошлого века. Он принимал активное участие в раскопках энеолитических поселений Кожай 1 , Кумкешу 1 и других памятников на территории Кустанайской области. При его непосредственном участии разрабатывалась концепция кочевого образа жизни терсекского населения энеолитического Тургая. К кустанайскому периоду относится и формирование его интереса к синташтинско-петровским древностям. Он принимал активное участие в раскопках и последующем осмыслении такого феномена, как могильник Бестамак (рис. 2). Позднее, уже переехав в Челябинск, он продолжал сохранять активные контакты с исследователями Тургая. Леонид Леонидович был ярким человеком с разносторонними интересами. В отличие от многих исследователей естествен-

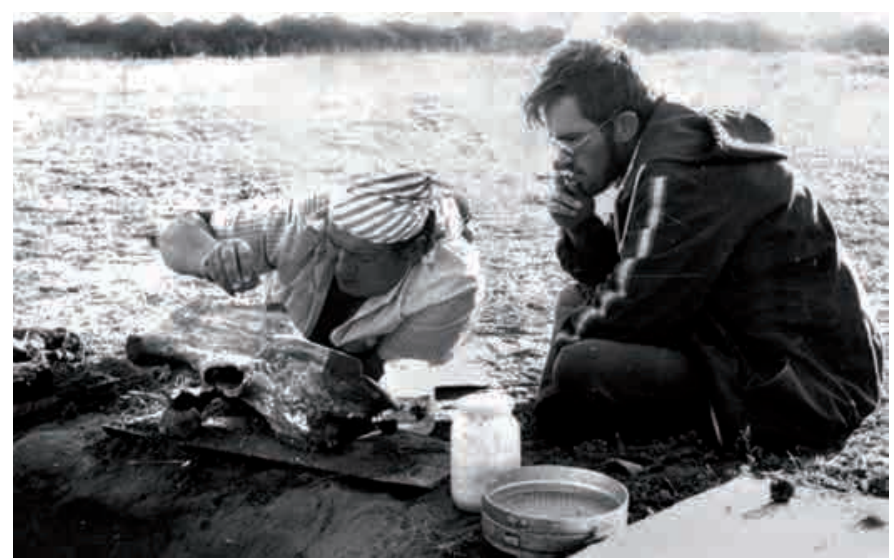

Рис. 2. Л.Л. Гайдученко и Ю. Лохматов. Могильник Бестамак, 1991. Расчистка черепа лошади. Архив А.В. Логвина и И.В. Шевниной

2-сур. Л.Л. Гайдученко мен Ю. Лохматов. Бестамақ қорымы, 1991. Жылқының бас сүйгін тазарту. А.В. Логвин мен И.В. Шевнинаның архивінен

Fig. 2. L. Gayduchenko and Yu. Lokhmatov. Burial ground Bestamak, 1991. Clearing the horse skull. Archive of A. Logvin and I. Shevnina 
ников, изучающих археологические комплексы, он не был зашорен. Это предопределило неординарность многих предлагавшихся им подходов к изучению фактического материала и создаваемых на этой основе реконструкций жизнедеятельности древних обществ. Предлагаемые им концепции всегда встречали у исследователей неоднозначную оценку, но они никогда не оставляли их равнодушными».

А.В. Логвин, И.В. Шевнина: «Лев урало-казахстанских степей.... Путь в археологической науке у Леонида Леонидовича Гайдученко был неразрывно связан с Тургайской археологической экспедицией. Потом было много экспедиций и переезд в Россию, но интересы в археологии были определены именно в ней. А в нашей экспедиции его не называли по имени отчеству, для всех он был Леонидычем. Статный, уверенный в себе мужчина, с пышной шевелюрой и зычным голосом ... Лев уралоказахстанских степей.

Именно Леонидыч нашел курган Халвай 5. Дело было весной, уже после того как мы раскопали курган
Халвай 3, в гости приехал Леонидыч и попросил: “Андрюха, а свози меня на Халвай”. Посмотрев курган, уже на пути домой, Леонидыч, махнув рукой, спросил Андрея: “А что это там?" Подъехав поближе, стало ясно, что это курган и по виду это был “братблизнец” Халвая 3. Тем летом мы копали именно его, а Леонидыч был с нами...».

Bce, с кем мы говорили о нем, едины во мнении - как много он еще мог сделать и как жаль, что уже не сделает. Трудно представить, сколько исхожено и изъезжено степных дорог этим человеком, сколько интересных идей высказано и, самое главное, совершенно невозможно принять, что его уже нет с нами.

Л.Л. Гайдученко разрабатывал актуальные вопросы археологического изучения Урало-Казахстанских степей - палеоэкологии, эволюции хозяйственной деятельности, развития древних технологий. Заложенные им знания представляют необходимое звено в процессе фундаментального изучения культуры древнего населения региона.

\section{ЛИТЕРАТУРА}

1. Гайдученко Л.Л. Новая верхнепалеолитическая стоянка на Иртыше // Проблемы археологии и этнографии Сибири: тез. докл. к регион. конф. (г. Иркутск, 5-9 апреля 1982 г.) / Г.И. Медведев (отв. ред.). Иркутск: Иркут. ун-т, 1982. С. 26-27.

2. Гайдученко Л.Л. Позвоночные, палеоландшафты и палеоклиматы неогена Павлодарского Прииртышья: автореф. дис. ... канд. геол.-мин. наук. Новосибирск: ИГГ СО РАН, 1986. $17 \mathrm{c}$.

3. Гайдученко Л.Л. Крупный рогатый скот энеолита степной зоны Казахстана (доместикационные признаки на черепе и нижней челюсти) // Вопросы археологии Казахстана: сб. науч. тр. / З. Самашев (отв. ред.). Алматы-М.: Гылым, 1998. Вып. 2. C. 175-178.

4. Гайдученко Л.Л. Особенности природопользования древнего населения «Страны городов» Южного Урала и Зауралья // Комплексные общества Центральной Азии в III-I тыс. до. н.э.: региональные особенности в свете универсальных моделей. М-лы к конф. Челябинск: Челяб гос. ун-т, 1999. С. 309-311.

5. Гайдученко Л.Л. Композитная пища и освоение пищевых ресурсов населением Урало-Казахстанских степей в эпоху неолита-бронзы // Археологический источник 
и моделирование древних технологий: тр. музея-заповедника «Аркаим». Челябинск: Центр «Аркаим»; Институт истории и археологии УрО РАН, 2000. С. 150-169.

6. Гайдученко Л.Л. О функции лентообразной выкладки из костей животных у наружного основания оборонительной стены протогорода Куйсак // Этнические взаимодействия на Южном Урале: тез. докл. регион. науч.-практ. конф. Челябинск: Челяб. гос. ун-т, 2002. С. 23-25.

7. Гайдученко Л.Л. Этапы развития молочного хозяйства у населения древности Урало-Казахстанских степей // Зыряновские чтения: м-лы III межрегион. науч.-практ. конф. (г. Курган, 23-24 ноября 2005 г.). Курган: Изд-во Курганского ун-та, 2005. С. 21-22.

8. Гайдученко Л.Л. Жертвенный комплекс ямы № 5 могильника Бестамак // Археология Казахстана в эпоху независимости: итоги, перспективы. М-лы междунар. науч. конф., посвящ. 20-летию Независимости РК и 20-летию ИА КН МОН РК / Б.А. Байтанаев (гл. ред.), А.З. Бейсенов (отв. ред.). Алматы: Институт археологии им. А.Х. Маргулана, 2011. Т. 1. С. 341-348.

9. Гайдученко Л.Л. Особенности сложения жертвенного комплекса ямы № 170 могильника Бестамак // Археология Казахстана в эпоху независимости: итоги, перспективы. М-лы науч. конф. посвящ. 20-летию Независимости РК и 20-летию ИА КН МОН РК / Б.А. Байтанаев (гл. ред.), А.З. Бейсенов (отв. ред.). Алматы: Институт археологии им. А.Х. Маргулана, 2011а. Т. І. С. 349-359.

10. Гайдученко Л.Л. Остеологический комплекс поселения Токсанбай // Труды филиала Института археологии им. А.Х. Маргулана в г. Астане. 2012. Т. 1. С. 160-170.

11. Гайдученко Л.Л. Остеологические материалы стоянки Токтаул (предварительное сообщение) // Артюхова О.А., Курманкулов Ж., Ермолаева А.С., Ержанова А.Е. Комплексное изучение памятников в урочище Талдысай. Алматы: Институт археологии им. А.Х. Маргулана, 2013. С. 83-89.

12. Гайдученко Л.Л. Археозоологическое исследование костей животных // Артюхова О.А., Курманкулов Ж., Ермолаева А.С., Ержанова А.Е. Комплексное изучение памятников в урочище Талдысай. Алматы: Институт археологии им. А.Х. Маргулана, 2013a. C. 353-363.

13. Гайдученко Л.Л. Остатки кровавых жертвоприношений из кургана Халвай III // Шевнина И., Логвин А. Могильник эпохи бронзы Халвай III в Северном Казахстане. Материалы и исследования по археологии Казахстана. T. VII. Астана: Филиал Института археологии им. А.Х. Маргулана в г. Астана, 2015. С. 198-207.

14. Гайдученко Л.Л. Пищевые пригары из жертвенных сосудов из кургана Халвай III // Шевнина И., Логвин А. Могильник эпохи бронзы Халвай III в Северном Казахстане. Материалы и исследования по археологии Казахстана. T. VII. Астана: Филиал Института археологии им. А.Х. Маргулана в г. Астана, 2015а. С. 244.

15. Гайдученко Л.Л. Археобиологические остатки из раскопок поселения эпохи бронзы Конезавод I в Среднем Притоболье // Древний Тургай и Великая Степь: часть и целое. Сб. науч. ст., посвящ. 70-летнему юбилею В.Н. Логвина / А.З. Бейсенов (отв. ред). Костанай-Алматы: Институт археологии им. А.Х. Маргулана, 2015б. С. 167-183.

16. Гайдученко Л.Л. Остеологические остатки из кургана 6 могильника Таксай $1 / /$ Вопросы истории и археологии Западного Казахстана. 2015в. № 2. С. 210-217.

17. Гайдученко Л.Л. Пищевые пригары из керамических сосудов поселения эпохи бронзы Конезавод I// Древний Тургай и Великая Степь: сб. науч. ст., посвящ. 70-летнему юбилею В.Н. Логвина. Костанай-Алматы: Институт археологии им. А.Х Маргулана, 2015г. C. 184-185.

18. Гайдученко Л.Л. Археозоологические материалы из раскопок Кумкешу 1 // Калиева С.С., Логвин В.Н. Поселение Кумкешу 1 - эталонный памятник терсекской культуры. Материалы и исследования по археологии Казахстана. T. IX. Астана: Қазақ ғылыми-зерттеу мәдениет институтының баспа тобы, 2017. С. 282-301.

19. Гайдученко Л.Л., Жегало В.И., Зажигин В.С. Павлодарское местонахождение гиппарионовой фауны «Гусиный переплет» // Бюл. МОИП. Отдел геолог. 1978. Т. 53. Вып. 4. С. 147. 
20. Гайдученко Л.Л., Зайберт В.Ф., Косинщев П.А., Пластеева Н.А. Лошади ботайской и терсекской археологических культур // Этнические взаимодействия на Южном Урале: сб. науч. тр. Челябинск: Рифей, 2013. С. 268-270.

21. Гайдученко Л.Л., Зданович Г.Б. Расчеты величин биомассы и поедаемой массы тела копытных в археологических исследованиях // Археологический источник и моделирование древних технологий: тр. музея-заповедника Аркаим. Челябинск: СПЛиИАЦ «Аркаим», Ин-т истории и археологии УрО РАН, 2000. С. 45-72.

22. Гайдученко Л.Л., Зданович Д.Г. Пищевые пригары на сосудах из кургана 25 Большекараганского могильника // Аркаим: некрополь (по материалам кургана 25 Большекараганского могильника). Челябинск: Южно-Уральское книжное издательство, 2002. Кн. 1. С. 120-128.

23. Гайдученко Л.Л., Мери В.К. Остеологический комплекс поселения Борлы // Маргулановские чтения - 2012: м-лы ежегодной науч.-практ. конф. Астана: Филиал Института археологии им. А.Х. Маргулана в г. Астана, 2012. С. 27-29.

24. Гайдученко Л.Л., Калиева С.С., Логвин В.Н. О хозяйстве энеолитического населения Тургайского прогиба // Вопросы археологии Центрального и Северного Казахстана: сб. науч. тр. / В.В. Евдокимов (отв. ред.). Караганда: Карагандинский гос. ун-т, 1989. С. 27-33.

25. Гайдученко Л.Л., Кирюшин К.Ю. Пригары из керамических сосудов поселения Новоильинка-III в Северной Кулунде // Археология Западной Сибири и Алтая: опыт междисциплинарных исследований. Сб. ст., посвящ. 70-летию профессора Ю.Ф. Кирюшина / под ред. А.А. Тишкина. Барнаул: Изд-во Алт. ун-та, 2015. С. 106109.

26. Гайдученко Л.Л., Ломан В.Г. Фаунистический комплекс поселения Донгал в Центральном Казахстане // Археология Западной Сибири и Алтая: опыт междисциплинарных исследований. Сб. ст., посвящ. 70-летию профессора Ю.Ф. Кирюшина / под ред. А. А. Тишкина. Барнаул: Изд-во Алт. ун-та, 2015. С. 200 204.

27. Гайдученко Л.Л., Таймагамбетов Ж.К. Палеолитические местонахождения на озере Маралды в северо-восточном Казахстане // Проблемы археологии и этнографии Сибири: тез. докл. к регион. конф. (г. Иркутск, 7-9 апреля 1982 г.). / Г.И. Медведев (отв. ред.). Иркутск: Иркут. ун-т, 1982. С. 29-30.

28. Грушин С.П., Гайдученко Л.Л. Стратегия освоения пищевых ресурсов населением елунинской культуры лесостепного Обь-Иртышья (по материалам гистологического анализа пригаров на керамике) // Современные решения актуальных проблем евразийской археологии: сб. науч. ст. / А.А. Тишкин (отв. ред.). Барнаул: Издво Алт. ун-та, 2013. С. 280-282.

29. Калиева С.С., Гайдученко Л.Л., Логвин В.Н. К вопросу о сезонности поселения Кожай I // Актуальные проблемы методики западносибирской археологии: тез. докл. регион. науч. конф. (г. Новосибирск, 18-21 марта 1989 г.) / А.П. Деревянко (отв. ред.). Новосибирск: ИАЭт СО РАН, Тюменский гос. ун-т, 1989. С. 129-132.

30. Семинар-практикум в с. Чесма // Официальный сайт администрации Варненского муниципального района Челябинской области. URL: https://varna74.ru/ news/seminar-praktikum-v-s-chesma (дата обращения: 24.05.2021).

31. Спасем озеро Смолино // Официальный сайт РБК. URL: https://www.rbc. ru/companies/id/1027400009537-obschestvennoe-dvizhenie-chelyabinskoe-gorodskoeobschestvennoe-dvizhenie-spasem-ozero-smolino/(дата обращения 24.05.2021)

\section{REFERENCES}

1. Gayduchenko, L. L. 1982. In: Medvedev, G. I. (ed.). Problemy arheologii i etnografii Sibiri (Problems of archeology and ethnography of Siberia). Irkutsk: Irkutsk University, 2627 (in Russian).

2. Gayduchenko, L. L. 1986. Pozvonochnye, paleolandshafty i paleoklimaty neogena Pavlodarskogo Priirtyshiya (Vertebrates, paleolandscapes and paleoclimates of the 
Neogene of the Pavlodar Irtysh region): thesis of the Cand. geol.-min. sciences. Novosibirsk: V.S. Sobolev Institute of Geology and Mineralogy Siberian Branch of RAS (in Russian).

3. Gayduchenko, L. L. 1998. In: Samashev, Z. (ed.). Voprosy arheologii Kazahstana (Questions of archeology of Kazakhstan), 2, 175-178. Almaty-Moscow: "Gylym” Publ. (in Russian).

4. Gayduchenko, L. L. 1999. In: Kompleksnye obshchestva Centralnoy Azii v 3-1 tys. do n.e.: regionalnye osobennosti $v$ svete universalnyh modeley (Complex societies of Central Asia in the 3-1 millennium BC: regional features in the light of universal models). Chelyabinsk: Chelyabinsk State University, 309-311 (in Russian).

5. Gayduchenko, L. L. 2000. In: Arheologicheskiy istochnik i modelirovanie drevnih tekhnologiy (Archaeological source and modeling of ancient technologies). Chelyabinsk: Center "Arkaim"; Institute of History and Archeology Ural Branch of the Russian Academy of Sciences, 150-169 (in Russian).

6. Gayduchenko, L. L. 2002. In: Etnicheskie vzaimodeystviya na Yuzhnom Urale (Ethnic interactions in the Southern Urals). Chelyabinsk: Chelyabinsk State University, 23-25 (in Russian).

7. Gayduchenko, L. L. 2005. In: Zyryanovskie chteniya (Zyryanov readings). Kurgan: Kurgan University, 21-22 (in Russian).

8. Gayduchenko, L. L. 2011. In: Baitanayev, B. A., Beisenov, A. Z. (eds.). Arheologiya Kazahstana v epohu nezavisimosti: itogi, perspektivy (Archeology of Kazakhstan in the era of independence: results, prospects), 1, 341-348. Almaty: A.Kh. Margulan Archeology Institute (in Russian).

9. Gayduchenko, L. L. 2011a. In: Baitanayev, B. A., Beisenov, A. Z. (eds.). Arheologiya Kazahstana v epohu nezavisimosti: itogi, perspektivy (Archeology of Kazakhstan in the era of independence: results, prospects), 1, 349-359. Almaty: A.Kh. Margulan Archeology Institute (in Russian).

10. Gayduchenko, L. L. 2012. In: Trudy Filiala Instituta arheologii im. A.H. Margulana v g. Astane (Proceedings of the Branch of the A.Kh. Margulan Archeology Institute in Astana), 1, 160-170 (in Russian).

11. Gayduchenko, L. L. 2013. In: Artyukhova, O. A., Kurmankulov, Zh., Ermolaeva, A. S., Erzhanova, A. E. Kompleksnoe izuchenie pamyatnikov $v$ urochishche Taldysay (Comprehensive study of monuments in the Taldysai). Almaty: A.Kh. Margulan Archeology Institute, 83-89 (in Russian).

12. Gayduchenko, L. L. 2013a. In: Artyukhova, O. A., Kurmankulov, Zh., Ermolaeva, A. S., Erzhanova, A. E. Kompleksnoe izuchenie pamyatnikov $v$ urochishche Taldysay (Comprehensive study of monuments in the Taldysai). Almaty: A.Kh. Margulan Archeology Institute, 353-363 (in Russian).

13. Gayduchenko, L. L. 2015. In: Shevnina, I., Logvin, A. Mogilnik epohi bronzy Halvay 3 v Severnom Kazahstane. Materialy i issledovaniya po arheologii Kazahstana. T. VII (Burial ground of the Bronze Age Khalvay 3 in Northern Kazakhstan. Materials and research on the archeology of Kazakhstan. T. VII). Astana: Branch of the A.Kh. Margulan Archeology Institute in Astana, 198-207 (in Russian).

14. Gayduchenko, L. L. 2015a. In: Shevnina, I., Logvin, A. Mogilnik epohi bronzy Halvay 3 v Severnom Kazahstane. Materialy i issledovaniya po arheologii Kazahstana. T. VII (Burial ground of the Bronze Age Khalvay 3 in Northern Kazakhstan. Materials and research on the archeology of Kazakhstan. T. VII). Astana: Branch of the A.Kh. Margulan Archeology Institute in Astana, 244 (in Russian).

15. Gayduchenko, L. L. 2015б. In: Beisenov, A. Z. (ed.). Drevniy Turgay i Velikaya Step: chast $i$ tseloe (Ancient Turgay and the Great Steppe: part and whole). Kostanay-Almaty: A.Kh. Margulan Archeology Institute, 167-183 (in Russian).

16. Gayduchenko, L. L. 2015B. In: Voprosy istorii i arheologii Zapadnogo Kazahstana (Questions of history and archeology of Western Kazakhstan), 2, 210-217 (in Russian).

17. Gayduchenko, L. L. 2015r. In: Beisenov, A. Z. (ed.). Drevniy Turgay i Velikaya Step: chast $i$ tseloe (Ancient Turgay and the Great Steppe: part and whole). Kostanay-Almaty: A.Kh. Margulan Archeology Institute, 184-185 (in Russian). 
18. Gayduchenko, L. L. 2017. In: Kalieva, S. S., Logvin, V. N. Poselenie Kumkeshu 1 etalonnyi pamyatnik tersekskoy kultury. Materialy i issledovaniya po arheologii Kazahstana. T. IX (The settlement of Kumkeshu 1 is a reference monument of the Tersek culture. Materials and research on the archeology of Kazakhstan. T. IX). Astana: Kazakh scientific-research Culture Institute, 282-301 (in Russian).

19. Gayduchenko, L. L., Zhegalo, V. I., Zazhigin, V. S. 1978. In: Byulleten Moskovskogo obshchestva ispytateley prirody. Otdel geolog (Bulletin of the Moscow Society of Naturalists. Department of geologist), 53.4, 147 (in Russian).

20. Gayduchenko, L. L., Zaibert, V. F., Kosintsev, P. A., Plasteeva, N. A. 2013. In: Etnicheskie vzaimodeystviya na Yuzhnom Urale (Ethnic interactions in the South Urals). Chelyabinsk: "Rifey" Publ., 268-270 (in Russian).

21. Gayduchenko, L. L., Zdanovich, G. B. 2000. In: Arheologicheskiy istochnik i modelirovanie drevnih tekhnologiy (Archaeological source and modeling of ancient technologies). Chelyabinsk: "Arkaim", Institute of History and Archeology of the Ural Branch of the Russian Academy of Sciences, 45-72 (in Russian).

22. Gayduchenko, L. L., Zdanovich, D. G. 2002. In: Arkaim: nekropol (po materialam kurgana 25 Bolshekaraganskogo mogilnika) (Arkaim: necropolis (based on materials from mound 25 of the Bolshekaragan burial ground), 1, 120-128. Chelyabinsk: Yuzhno-Uralskoe knizhnoe izdatelstvo (in Russian).

23. Gayduchenko, L. L., Merts, V. K. 2012. In: Margulan readings-2012. Astana: Branch of the A.Kh. Margulan Archeology Institute in Astana, 27-29 (in Russian).

24. Gayduchenko, L. L., Kalieva, S. S., Logvin, V. N. 1989. In: Evdokimov, V. V. (ed.). Voprosy arheologii Centralnogo i Severnogo Kazahstana (Questions of archeology of Central and Northern Kazakhstan). Karaganda: Karaganda State University, 27-33 (in Russian).

25. Gayduchenko, L. L., Kiryushin, K. Yu. 2015. In: Tishkin, A. A. (ed.). Arheologiya Zapadnoy Sibiri i Altaya: opyt mezhdisciplinarnyh issledovaniy (Archeology of Western Siberia and Altay: experience of interdisciplinary research). Barnaul: Altay State University, 106-109 (in Russian).

26. Gayduchenko, L. L., Loman, V. G. 2015. In: Tishkin, A. A. (ed.). Arheologiya Zapadnoy Sibiri i Altaya: opyt mezhdisciplinarnyh issledovaniy (Archeology of Western Siberia and Altay: experience of interdisciplinary research). Barnaul: Altay State University, 200-204 (in Russian).

27. Gayduchenko, L. L., Taymagambetov, Zh. K. 1982. In: Medvedev, G. I. (ed.). Problemy arheologii i etnografi Sibiri (Problems of archeology and ethnography of Siberia). Irkutsk: Irkutsk University, 29-30 (in Russian).

28. Grushin, S. P., Gayduchenko, L. L. 2013. In: Tishkin, A. A. (ed.). Sovremennye resheniya aktualnyh problem evraziyskoy arheologii (Modern solutions of actual problems of Eurasian archeology). Barnaul: Altay State University, 280-282 (in Russian).

29. Kalieva, S. S., Gayduchenko, L. L., Logvin, V. N. 1989. In: Derevyanko, A. P. (ed.). Aktualnye problemy metodiki zapadnosibirskoy arheologii (Actual problems of the methodology of Western Siberian archeology). Novosibirsk: Institute of archeology and ethnography SB RAS, Tyumen State University, 129-132 (in Russian).

30. Official site of the administration of the Varna municipal district of the Chelyabinsk region. URL: https://varna74.ru/news/seminar-praktikum-v-s-chesma (24.05.2021) (in Russian).

31. Official site of RBK. URL: https://www.rbc.ru/companies/id/1027400009537obschestvennoe-dvizhenie-chelyabinskoe-gorodskoe-obschestvennoe-dvizhenie-spasemozero-smolino/ (24.05.2021) (in Russian).

Мақала туралы ақпарат / Информация о статье / Information about the article.

Жариялауға қабылданды / Принята к публикации / Accepted for publication: 30.05.2021. 